Annales Missiologici Posnanienses t. 20 (2015), s. 33-42

DOI: $10.14746 / \mathrm{amp} .2015 .20 .3$

ANITA MAGOWSKA

Uniwersytet Medyczny w Poznaniu / Poznań University of Medical Sciences

\title{
O opiece zdrowotnej w Ugandzie, drugiej Ojczyźnie dr Wandy Błeńskiej
}

\section{Pierwsze placówki medyczne a leprozoria w diecezji Jinji}

Uganda jest znana nie tylko z malowniczego krajobrazu, obejmującego kaskady Nilu i jezioro Wiktorii, ale także z najstarszego na tym kontynencie katolickiego systemu opieki zdrowotnej. Jego początki datują się na 1899 r., kiedy misjonarze katoliccy założyli szpital w Rubaga, wzorując się na Szpitalu Mengo w Kampali, dwa lata wcześniej założonym przez protestanckie Church Missionary Society z Anglii (Waite 97-120). Te szpitale nie były jednak podobne. Pierwszy utworzyli misjonarze pozbawieni wykształcenia medycznego, drugi, Szpital Mengo, został zorganizowany według angielskich wzorców przez lekarza i świeckiego misjonarza, Alberta Ruskina Cooka (1870-1951). Jego wolontariat w Mengo stał się głośny, kiedy opublikował na łamach „Journal of Tropical Medicine" pionierskie opisy chorób tropikalnych, głównie malarii i śpiączki afrykańskiej. Cook przebywał w Ugandzie od maja $1897 \mathrm{r}$. do marca 1901 r., lecząc 1500 pacjentów w szpitalu i 40000 ambulatoryjnie. Opracował ich historie chorób statystycznie, podkreślając, że 39\% pacjentów wymagało interwencji chirurgicznych, $9 \%$ ginekologiczno-położniczych, a pozostali cierpieli na ,choroby medyczne”. W ostatniej grupie przeważała malaria, w dalszej kolejności były choroby weneryczne, a chorzy na gruźlicę stanowili 5\% pacjentów Cooka (Foster 75-76).

Pierwszymi w Ugandzie placówkami leczenia trądu były szpitale utworzone przez Matkę Mary Kevin Kearney (1875-1957), irlandzką franciszkankę, która z czasem założyła Zgromadzenie Franciszkanek Misjonarek Afryki, a dziś jest kandydatką na ołtarze. Do Ugandy przybyła w 1903 r. i postanowiła zająć się trędowatymi, wtedy izolowanymi od społeczeństwa i pozostawiany- 
mi bez jakiejkolwiek pomocy medycznej. Władze brytyjskie przyznały jej nieodpłatnie tereny występowania śpiączki afrykańskiej w diecezji Jinji. Siostry wykarczowały krzewy, usuwając w ten sposób siedliska much tse-tse. Wraz $\mathrm{z}$ tymi owadami zniknęła przenoszona przez nie choroba.

W 1930 r. Matka Kevin otworzyła w Nyenga szpital dla chorych na niezakaźną postać trądu. Cztery lata później franciszkanki otworzyły w pobliskiej miejscowości Buluba szpital dla chorych na trąd zaraźliwy. W obu ośrodkach leczono 500-700 trędowatych rocznie, a drugie tyle przychodziło po pomoc medyczną do przychodni. Wśród sióstr były tylko pielęgniarki oraz laborantki, dlatego usilnie zabiegały o zatrudnienie lekarza. Na misje katolickie, w przeciwieństwie do protestanckich, mogli bowiem wyjeżdżać tylko zakonnicy i zakonnice, a wśród nich lekarzy było niewielu.

Matce Kevin udało się pozyskać lekarza dopiero w 1951 r. To była dr Wanda Błeńska (1911-2014), dobrze wyszkolona w zakresie chorób tropikalnych i energiczna, która natychmiast po przyjeździe zabrała się za modernizację obu szpitali, aby zwiększyć zakres udzielanej w nich pomocy medycznej. Kilka lat później, kiedy ośrodki w Nyenga i Buluba zostały już przez dr Błeńską zreformowane, odwiedził je dr Kinnear Brown, naczelny leprolog Ugandy. Poziom medyczny szpitali wywarł na nim duże wrażenie. Obiecał siostrom pomoc materialną i uzyskał ją z Deutsche Aussätzigen Hilfswerk z Würzburga, a także innych organizacji charytatywnych: Organizacji Narodów Zjednoczonych do Spraw Wyżywienia i Rolnictwa, British Emipre Leprosy Relief Association i Duńskiego Towarzystwa Przyjaciół Trędowatych. Dzięki pozyskanym środkom zamontowano szklany dach nad salą operacyjną, co wobec braku prądu pozwoliło dr Błeńskiej na wydłużenie czasu udzielania pomocy chirurgicznej. Buluba stała się ważnym ośrodkiem badań trądu i gruźlicy, uważanych przez Kinneara Browna za choroby pod pewnymi względami podobne. Tu testowano leczenie trądu sulfonami, a potem zalecaną przez Światową Organizację Zdrowia terapią wielolekową.

W 1956 r. otwarto w Bulubie jedną z dwóch ugandyjskich szkół kształcących pomocniczy personel medyczny w zakresie diagnozowania i leczenia trądu. Do szkoły przyjeżdżała młodzież nie tylko z Ugandy, ale i Kenii, Sudanu i Tanzanii. W latach 1956-1982 szkołę ukończyło 169 asystentów medycznych. Ponadto od 1962 r. wszyscy studenci medycyny musieli odbyć praktyki leprologiczne w Bulubie. Wykłady dla nich, a także dla uczniów wspomnianej szkoły, prowadziła dr Wanda Błeńska, która ponadto prowadziła zajęcia na najstarszej uczelni Ugandy, założonym w 1924 r. Uniwersytecie Makarere w Kampali. Obecnie w Ugandzie istnieje 8 uczelni państwowych i 30 prywatnych. Prawie wszystkie założono po $1989 \mathrm{r}$.

W 1929 r. otwarto w Bulubie Centrum Leczenia Trądu z pracowniami do badań nad chemioterapią i immunologią trądu oraz gruźlicy (Andrzejak 24- 
-25). Różnokierunkowe i fachowe działania doprowadziły do opanowania epidemii trądu w Ugandzie, co z czasem pozwoliło na przekształcenie leprozoriów w Nyenga oraz Bulubie w ośrodki leczenia gruźlicy i przekazanie ich diecezji w Jinji. O ile w połowie XX w. istniało w Ugandzie 20 leprozoriów, to pół wieku później tylko 7, w dodatku funkcjonujących nie jako szpitale, lecz wioski, w których w razie potrzeby podawane są leki. Dawne leprozorium w Bulubie to dziś cieszący się bardzo dobrą opinią Szpital św. Franciszka, w którym, niestety, o dr Błeńskiej zapomniano. Od jej wyjazdu minęło ponad 20 lat, a Afrykańczycy żyją dniem dzisiejszym, nie przeszłością. Na stronie internetowej Szpitala św. Franciszka w Bulubie został szeroko opisany tygodniowy pobyt amerykańskich chirurgów w 2008 r., ale o pracującej tu przez ponad 40 lat dr W. Błeńskiej nie ma ani słowa. Autorka poznała dra Sama Okuenzi ze szpitala w Bulubie, który o polskiej lekarce nic nie słyszał i z zadowoleniem przyjął materiały informujące o jej posłudze w Ugandzie (Hope Institute).

\section{Początki kościelnych systemów zdrowia}

Ośrodek, w którym podjęła pracę dr Wanda Błeńska, był jednym z wielu objętych w 1955 r. kuratelą Ugandyjskiego Katolickiego Urzędu Medycznego - Uganda Catholic Medical Bureau, UCMB, utworzonego przez Wydział Zdrowia tutejszej Konferencji Episkopatu dla zapewnienia wysokiego poziomu katolickich szpitali, ośrodków zdrowia i szkół pielęgniarskich. Katolickie systemy opieki zdrowotnej są fenomenem charakterystycznym dla państw Afryki subsaharyjskiej. Powstanie UCMB było nieodzowne dla zarządzania kilkuset placówkami lecznictwa otwartego i zamkniętego, w większości stanowiącymi dziedzictwo okresu kolonializmu (Magowska 51). W 1952 r. powstał Ugandyjski Protestancki Urząd Medyczny - Uganda Protestant Medical Bureau, służący rozwojowi protestanckich placówek opieki zdrowotnej. Uganda odzyskała niepodległość w 1962 r., a w 1979 r. oba urzędy zaczęły współpracować i utworzyły wspólną hurtownię farmaceutyczną, która z czasem uniezależniła się od fundatorów.

Tak powstawały kościelne systemy opieki zdrowotnej, tylko pod niektórymi względami podobne do misji medycznych $\mathrm{w}$ okresie kolonialnym. Najistotniejszą różnicą było dążenie do profesjonalizacji i koordynacji działań przez administratora podlegającego władzom kościelnym. W UCMB odpowiedzialność za sprawne funkcjonowanie systemu spoczywała na siostrze zakonnej $\mathrm{z}$ uprawnieniami pielęgniarki, która dodatkowo ukończyła kursy medycyny tropikalnej i pierwszej pomocy medycznej. Była ona zobowiązana do pracy biurowej w Urzędzie Zdrowia, a także - wobec braku kwalifikowanego personelu 
medycznego - do dyspensowania leków, zmieniania opatrunków, przeprowadzania drobnych zabiegów chirurgicznych, wydawania posiłków dla niedożywionych dzieci, kształcenia miejscowej ludności w zakresie higieny, a w razie potrzeby przeistaczała się $\mathrm{w}$ położną. Przepracowana nie była $\mathrm{w}$ stanie wypełnić wszystkich obowiązków, a zwłaszcza dostarczyć statystyk medycznych, niedocenianego wtedy fundamentu opieki medycznej. W tym okresie także sektor państwowy nie troszczył się o prowadzenie badań demograficznych czy też dokumentacji i statystyk medycznych. W rezultacie nie znano nawet liczby mieszkańców Ugandy, a co dopiero przyczyn ich umieralności.

Pierwszy w niepodległej Ugandzie spis ludności został przeprowadzony w 1969 r. i wykazał 9,5 miliona mieszkańców. Od następnego roku Uganda stała się celem migracji setek tysięcy uchodźców z dotkniętych wojnami domowymi Rwandy, Burundi oraz Sudanu. Genezy konfliktów etnicznych można doszukać się jeszcze w początkach kolonializmu, gdy granice państw afrykańskich wytyczano w sztuczny sposób, według interesów europejskich mocarstw, bez uwzględniania rozmieszczenia plemion i ludów Czarnego Lądu. Z drugiej strony do wzniecania wojen domowych przyczyniały się zasoby naturalne Afryki subsaharyjskiej, np. znajdujące się na terytorium Sudanu plantacje drzew akacjowych, dostarczające zagęstników dla światowego przemysłu spożywczego.

W 1989 r., gdy liczba mieszkańców Ugandy była szacowana na 16,9 miliona, zaczął się proces odwrotny, czyli exodus setek tysięcy Ugandyjczyków do Kenii, Zairu i Sudanu, a więc na tereny w mniejszym stopniu dotknięte terrorem rebeliantów z Armii Pana - Lord's Army, później znanej jako Armia Bożego Oporu - Lord's Resistance Army. Ta założona w 1986 r. przez samozwańczego proroka Josepha Kony'ego, organizacja terrorystyczna dopuszczała się mordów i przemocy na zamieszkujących północną Ugandę plemionach Acholi (Branach 2). Dr Błeńska była ich świadkiem i kiedy w 1991 r. wróciła do Polski, opowiadała o tragedii Ugandyjczyków, których wioski grabiły i paliły oddziały Kony'ego, jednocześnie uprowadzając dzieci, by wcielić je do Armii Pana. Przeznaczane do usług seksualnych dziewczynki piętnowano obcięciem warg, tak, że nigdy nie mogły zamknąć ust. Chłopców, nawet pięcioletnich, zmuszano do udziału w napaści na rodzinną wioskę i zabiciu rodziców. Złamani moralnie i pozbawieni możliwości powrotu, stawali się żołnierzami Kony'ego przeznaczanymi do walki na pierwszej linii, bo gdy ginęli, łatwo ich było zastąpić kolejnymi porwanymi dziećmi, których w sumie uprowadzono około 30 000. W poznańskim okresie swojego życia dr Błeńska chętnie pożyczała książkę o zbrodniach ugandyjskich rebeliantów, prosząc o popularyzowanie jej treści, ponieważ światowe media są obojętne wobec tragedii Ugandyjczyków (Gus 196-197). Na tej podstawie w 2001 r. przygo- 
towałam krótki artykuł do czasopisma „Fakty AM”, wydawanego przez Akademię Medyczną w Poznaniu.

\section{Decentralizacja opieki medycznej}

W obliczu globalnego kryzysu, jaki w krajach rozwiniętych zaznaczył się w końcu lat siedemdziesiątych XX w., Bank Światowy zmienił strategię udzielania pomocy bezzwrotnej państwom subsaharyjskim, warunkując przyznawanie dotacji na opiekę zdrowotną częściową prywatyzacją usług medycznych (World Bank; de Becker et al. 169-176). W 1986 r. rząd Ugandy, podobnie jak władze Botswany, Ghany, Senegalu i Zambii, został więc zmuszony do decentralizacji przejętego z czasów kolonialnych systemu opieki zdrowotnej i przerzucenia odpowiedzialności za finansowanie i dostarczanie świadczeń zdrowotnych na władze lokalne. Tak doszło do wprowadzenia opłat za leczenie i medykamenty, na które w biednych państwach afrykańskich niewielu chorych mogło sobie pozwolić. Wobec niemożności zrealizowania jakiejkolwiek racjonalnej polityki zdrowotnej władze państw subsaharyjskich w większym niż dotychczas stopniu oparły się na Kościołach chrześcijańskich jako świadczeniodawcach usług medycznych. Zaczęły z nimi współpracować i wspomagać kontraktami kościelne placówki opieki zdrowotnej (Hanson i Berman 195-211). W tym czasie państwowe systemy opieki zdrowotnej były w Afryce subsaharyjskiej postrzegane jako niewydolne, dlatego pacjenci nie chcieli płacić za kiepskie świadczenia w przychodniach i szpitalach rządowych, natomiast akceptowali drobne opłaty obowiązujące w pozarządowych placówkach medycznych, w większości kościelnych, którym coraz więcej rządów państw afrykańskich powierzało zadania z zakresu podstawowej opieki zdrowotnej (Upleakar 897-904).

W Ugandzie utworzono jednostki administracji terenowej i w ramach decentralizacji opieki medycznej przekazano im odpowiedzialność za zapewnianie świadczeń medycznych, działalność szpitali i przychodni oraz inne dotychczasowe kompetencje resortu zdrowia. W 1997 r. jednostki te objęły swoim nadzorem także kościelne placówki medyczne, w tym szpitale. Utworzono rady szpitalne, złożone z lokalnych polityków, przywódców religijnych i prominentnych obywateli, jednak zawsze kierowane przez miejscowego biskupa. W latach 1997-1998 rząd Ugandy przeznaczył na potrzeby szpitali prowadzonych przez organizacje pozarządowe, w tym kościelne, pokaźną jak na realia Afryki kwotę 100000 dolarów. Część szpitali kościelnych dodatkowo otrzymała środki z funduszy międzynarodowych na walkę z zakażeniami HIV (Hanson et al. 73-94). 
Po decentralizacji relacje między rządem a prywatnym sektorem świadczeń zdrowotnych przyjęły formę partnerstwa publiczno-prywatnego, utworzonego głównie dla poprawy zaopatrzenia w leki na choroby tropikalne, w tym trąd, filariozę i śpiączkę afrykańską. Autonomia szpitali, kontraktowanie usług medycznych i współpraca z lokalnymi władzami wzmocniły - dotychczas izolowany - katolicki system opieki zdrowotnej w Ugandzie. Integracja kościelnych placówek z narodowym systemem opieki zdrowotnej przyczyniła się do rozwiązania szeregu problemów, w tym - wynikającej z braku kadr medycznych i pieniędzy - bezsilności wobec potrzeb zdrowotnych sierot, kalek, starców i terminalnie chorych (Streefland 379-380). Uganda jako pierwsze państwo afrykańskie zapewniła opiekę paliatywną dla chorych na AIDS i nowotwory. Przyczynił się do tego jej udział w projekcie koordynowanym przez Światową Organizację Zdrowia, w którym uczestniczyły także Botswana, Etiopia, Tanzania, RPA i Zimbabwe (Stjernswärd 257-65).

Wedle ostatnich osiągalnych dla autorki danych z 2000 r. Ugandyjski Katolicki Urząd Zdrowia prowadził 255 z 1512 placówek medycznych i 11 z 27 szkół pielęgniarskich istniejących w tym kraju, zatrudniając 4257 osób w szpitalach i $2041 \mathrm{w}$ ośrodkach zdrowia (Magowska 51). Dzięki przyjęciu przez Konferencję Episkopatu Ugandy odpowiedzialności za działalność kościelnych placówek medycznych nie dotknął ich kryzys zaznaczający się w sektorze państwowym większości państw subsaharyjskich. Dziś na katolicki system opieki zdrowotnej w Ugandzie składają się 32 szpitale z 12 szkołami przyszpitalnymi, szkoła diagnostyki laboratoryjnej i 252 ośrodki zdrowia, zatrudniające 8225 pracowników fachowych i zapewniające pomoc medyczną dziesiątkom tysięcy mieszkańców tego kraju (The Health Department). Obecnie Urząd odpowiada za: strategie działalności, zarządzanie informacją, międzynarodową współpracę z Kościołami chrześcijańskimi, a także współpracę z dwoma ugandyjskimi uniwersytetami w Nkozi i Kampali. Funkcjonowanie systemu jest finansowane przede wszystkim z opłat pacjentów - średnio 36,5\%, ale w niektórych szpitalach nawet $51 \%$ dochodów pochodzi od chorych, ponadto z dotacji budżetu państwa - zwykle około 30\%, wreszcie z zagranicznych ofiar i innych źródeł (Lochoro).

\section{Sytuacja zdrowotna Ugandy w XXI w.}

Wszystkie osiągnięcia nie mogą przysłonić faktu, że w latach 2000-2001 stan zdrowia Ugandyjczyków pogorszył się, a zakres dostarczanych świadczeń medycznych zmniejszył się w stosunku do sytuacji sprzed pięciu lat. Co prawda umieralność niemowląt i matek pozostawała na tym samym poziomie, ale wzrosła zachorowalność na malarię, a odsetek w pełni zaszczepionych dzieci 
zmniejszył się z 47\% do 37\%. To oznaczało, że państwowy sektor opieki zdrowotnej nie spełniał oczekiwań, a katolickie placówki medyczne musiały przejmować jego zadania. Średnia długość życia Ugandyjczyków wynosiła wtedy 53 lata - dla porównania w Europie 79 lat (Jeppsson et al. 311-320).

Nową próbą rozwiązania trudnych problemów zdrowotnych ludności Afryki, w tym Ugandy, jest utworzona w 2007 r. platforma współpracy kościelnych organizacji zajmujących się zdrowiem Afrykańczyków - Africa Christian Health Associations Platform, ACHAP. Powstała podczas konferencji tych organizacji w Bagamoyo w Tanzanii celem koordynacji wysiłków na rzecz zapewnienia pomocy medycznej dla ludzi dotąd najbardziej zaniedbanych pod względem zdrowotnym, a więc np. starców i dzieci chorych na AIDS. Obecnie należy do niej 31 stowarzyszeń kościelnych z 26 państw subsaharyjskich, a sekretariat znajduje się w Nairobi, stolicy Kenii. Ogrom trudności, z jakimi boryka się ACHAP, unaocznia problem porozumiewania się. Afrykę cechuje bowiem wielość języków i narzeczy, które zwykle mają charakter fonetyczny i nie mają własnego pisma. Na poziomie międzynarodowym konieczne jest posługiwanie się jednym $\mathrm{z}$ języków europejskich, ale w tym zakresie przeszkadza podział na Afrykę Frankofońską i Anglofońską, zakorzeniony jeszcze w erze kolonialnej. Niewielu Afrykańczyków włada jednocześnie francuskim i angielskim. Trudnościom komunikowania towarzyszą trudności finansowe (Africa Christian Health Associations Platform). Czy afrykańskie katolickie systemy opieki medycznej mają więc szanse na integrację i rozwój?

W 2013 r. w Ugandzie mieszkało 37579000 osób, jednak według innych szacunków 30000000 lub nawet tylko 20000000 osób, a średnia życia wynosiła 57 lat. Do głównych przyczyn umieralności należały: niedożywienie, zwłaszcza niemowląt, a także malaria, nowotwory (poszukuje się związku przyczynowego między niektórymi chorobami pasożytniczymi a zachorowaniami na nowotwory), gruźlica i AIDS (często występujące razem). To właśnie w Ugandzie zdiagnozowano w 1982 r. pierwsze zgony z powodu AIDS. W tej dekadzie kraj ten osiągnął najwyższy na świecie wskaźnik zachorowań na AIDS, bowiem 15 przypadków na 100000 mieszkańców. O ile w 1989 r. chorowało na AIDS 7537 osób, to rok później notowano 17400 przypadków, a liczba ta podwajała się co pół roku. Tylko w Kampali żyło w tym czasie ponad 790000 ludzi zarażonych HIV, obecnie jest ich prawie dwa razy więcej. W Ugandzie połowa zarażonych HIV to dzieci.

Z perspektywy dziesiątkującej najmłodsze pokolenie plagi AIDS pierwszoplanowym zadaniem rządu Ugandy jest - poza wyciszeniem konfliktów zbrojnych, które niszczą gospodarkę i degradują zdrowie społeczeństwa - także zapewnienie opieki półtoramilionowej rzeszy dzieci osieroconych przez rodziców zmarłych na AIDS. Prawdopodobnie w ciągu najbliższych 20 lat liczba takich sierot potroi się, co będzie stanowić wyzwanie humanitarne nie 
tylko dla Ugandyjczyków, ale i społeczności międzynarodowej. Obecnie część z sierot żyje w drastycznych warunkach na ulicach miast, niektóre znajdują opiekę krewnych (w Afryce więzi plemienne i rodzinne są nadal bardzo silne), jeszcze inne - udręczone bezdomnością i głodem - przyłączają się do armii jako tzw. kadogos - dzieci-żołnierze.

Porównując te problemy z sytuacją sprzed lat, kiedy w Ugandzie pracowała dr Wanda Błeńska, a głównym problemem miejscowej ludności pozostawała bieda i ściśle z nią związane zachorowania na trąd, trzeba zauważyć wiele nowych i niekorzystnych procesów społecznych, wobec których Afrykańczycy są bezsilni. Procesy te mają złożony charakter i zostały zapoczątkowane jeszcze w czasach kolonialnych. Nie oznacza to jednak, że współczesna Europa i Ameryka oraz międzynarodowe instytucje finansowe nie ponoszą za nie odpowiedzialności.

Według oficjalnych statystyk, w Ugandzie na tysiąc mieszkańców przypada średnio 0,1 lekarza, a być może jeszcze mniej, ponieważ w stolicy kraju, Kampali, prywatną praktykę prowadzi zaledwie 36 lekarzy. Dla porównania, w Polsce na tysiąc mieszkańców przypada statystyczne 2,1 lekarza; w Szwajcarii 4,1; w całej Unii Europejskiej 3,1, a w USA średnio 2,4 lekarza (Kozakiewicz i Chodorski 5-6). Jeszcze gorzej wypadają ugandyjskie statystyki dotyczące opieki stomatologicznej: na 100000 mieszkańców przypada mniej niż 0,1 dentysty, dla porównania, w USA 60 dentystów na 100000 osób. Prawdopodobnie w całej Ugandzie pracuje 10-30 lekarzy dentystów. Absolwenci ugandyjskich uczelni medycznych są bowiem skutecznie rekrutowani przez wyspecjalizowane agencje do Anglii, Szwajcarii, USA, Kanady i innych państw borykających się z problemem starzejących społeczeństw i ich potrzeb zdrowotnych, a oferujących czarnoskórym lekarzom wyższe zarobki i lepsze warunki życia niż jakiekolwiek państwo subsaharyjskie.

Ogłoszony w 2010 r. z inicjatywy Światowej Organizacji Zdrowia i międzynarodowych organizacji charytatywnych działających na rzecz państw Trzeciego Świata kodeks etyki rekrutacji personelu medycznego (,WHO Global Code of Practice on the International Recruitment of Health Personnel") to tylko z pozoru cenna inicjatywa. Kodeks ten nie ma mocy prawnej i żadne z państw rozwiniętych nie zrezygnowało z pozyskiwania lekarzy i pielęgniarek z państw rozwijających się, w tym Ugandy. Przejmowanie personelu medycznego z państw Trzeciego Świata jest dla ich ekonomii znacznie korzystniejsze niż zwiększenie nakładów na szkolnictwo medyczne. Istniejące dzięki wolontariuszom i strumieniowi pomocy humanitarnej z Europy oraz Ameryki Północnej afrykańskie katolickie placówki medyczne będą zatem jeszcze długo potrzebne, choć borykają się $\mathrm{z}$ wieloma trudnościami. Jednym z nich jest brak leków lub ich zła jakość. Zdarza się, że organizacje charytatywne dostarczają leki przeterminowane lub z krótką datą ważności albo medykamenty 
zostają - pod presją różnych grup interesu - zakupione w Indiach znanych $\mathrm{z}$ braku kontroli nad jakością leków. W rezultacie stosowania w Afryce niepełnowartościowych antybiotyków powstają lekooporne bakterie, w tym wielolekooporne prątki gruźlicy, swoista medyczna bomba z opóźnionym zapłonem (Center for African Studies).

Tak więc zaangażowanie dr Wandy Błeńskiej w leczenie trądu przyczyniło się w istotny sposób do zmniejszenia zakresu występowania tej choroby w Ugandzie. Dzisiaj pracownicy Szpitala św. Franciszka w Bulubie o polskiej lekarce nie pamiętają, ale to nie dziwi. Tych, z którymi współpracowała i których leczyła, w Bulubie już nie ma. Ponadto Afrykańczycy nie są skłonni do rozpamiętywania przeszłości wobec narastających i nierozwiązywalnych problemów teraźniejszości i niepewnej przyszłości. Lekarski perfekcjonizm i chrześcijański maksymalizm dr Błeńskiej pozostaje jednak znakiem czytelnym dla nas, tu, w Polsce.

\title{
CONCERNING HEALTHCARE IN UGANDA, THE SECOND HOMELAND OF DR WANDA BŁEŃSKA
}

\begin{abstract}
This article presents the development of healthcare in Uganda when Dr. Wanda Błeńska (1911-2014) worked there. The article aims to explain medical and cultural context of her activity as a doctor in Africa.
\end{abstract}

Keywords: healthcare in Uganda; missionary; Wanda Błeńska

Słowa kluczowe: opieka zdrowotna w Ugandzie; misjonarz; Wanda Błeńska

\section{BIBLIOGRAFIA}

Africa Christian Health Associations Platform. Dostęp 30.03.2015. <www.africachap.org> AllAfrica. Dostęp 25.03.2015. <www.allafrica.com>

Andrzejak, Ambroży. Różański, Jarosław. Medycyna i ewangelizacja. Rozmowy z Wanda Błeńska. Poznań: Papieski Wydział Teologiczny, 1996.

de Beyer, Joy A. Preker, S. Alexander. Feachem, G.A. Richard. "The role of the World Bank in international health: renewed commitment and partnership." Social Science and Medicine 50 (2000): 169-176.

Branch, Adam. "Neither Peace nor Justice: Political Violence and the Peasantry in Northern Uganda, 1986-1998." African Studies Quarterly 8 (2005): 1-31. 
Center for African Studies. Dostęp 25.03.2015. <www.africa.ufl.edu>

Foster, William D. The early history of scientific medicine in Uganda. Nairobi: East African Literature Bureau, 1970.

Gus, Martin. Understanding Terrorism: Challenges, Perspectives, and Issues. Thousand Oakes CA: SAGE Publications, 2006 [2nd edition].

Hanson, Kara et al., "Towards improving hospital performance in Uganda and Zambia: reflections and opportunities for autonomy." Health Policy 61 (2002): 73-94.

Hanson, Kara. Berman, Peter. "Private health care provision in developing countries: A preliminary analysis of levels and composition." Health Policy and Planning 13 (1998): 195-211.

Hope Institute of Uganda. Dostęp 27.03.2015. <http://www.hopeinstituteuganda.org>

Jeppsson, Anders et al. "The global-local dilemma of a Ministry of Health. Experiences from Uganda." Health Policy 72 (2005): 311-320.

Kozakiewicz, Jacek. Chodorski, Jacek. "Perspektywy zawodowe lekarzy specjalistów na obszarze Izb Lekarskich: Śląskiej i Dolnośląskiej - problemy demograficzne”. Dostęp 30.03.2015. $<$ http://www.izba-lekarska.org.pl/files/media_files/Referat-Perspektywy\%20zawodowe\%20 lekarzy\%20specjalist $\%$ C3\%B3w\%20na\%20obszarze $\% 20$ Izb\%20Lekarskich $\% 20 \% \mathrm{C} 5 \% 9 \mathrm{~A}$ 1\%C4\%85skiej\%20i\%20Dolno\%C5\%9B1\%C4\%85skiej\%20\%E2\%80\%93\%20problemy\%20 demograficzne.pdf $>$

Lochoro, Peter [sekretarz Uganda Catholic Medical Bureau w Kampali]. List do autorki z 15 stycznia 2004.

Magowska, Anita. Zaangażowanie Polaków w misyjna opiekę zdrowotna w Afryce. Poznań: Wydawnictwo Kontekst, 2007.

Stjernswärd, Jan. "Uganda: Initiating a Government Public Health Approach to Pain Relief and Palliative Care." Journal of Pain and Symptom Management 24 (2002): 257-65.

Streefland, Peter. "Public health care under pressure in sub-Saharan Africa." Health Policy 71 (2005): 375-382.

The Health Department of Uganda Episcopal Conference. Dostęp 4.11.2015. <http://www.ucmb. co.ug/>

Uganda Catholic Medical Bureau w Kampali. Informacja z przekazana autorce w $2004 \mathrm{r}$.

Uplekar, Mukund W. "Private health care". Social Science and Medicine 51 (2000): 897-904.

Waite, Gloria M. A History of Traditional Medicine and Health Care in Pre-Colonial East-Central Africa. Lewiston: Edwin Mellen Press, 1992.

World Bank, Sub-Saharan Africa: from crisis to sustainable growth. Washington: World Bank 1989.

Anita Magowska - dr hab. prof. UM, kierownik Katedry i Zakładu Historii Nauk Medycznych Uniwersytetu Medycznego w Poznaniu, zainteresowania naukowe: historia medycyny i farmacji. 


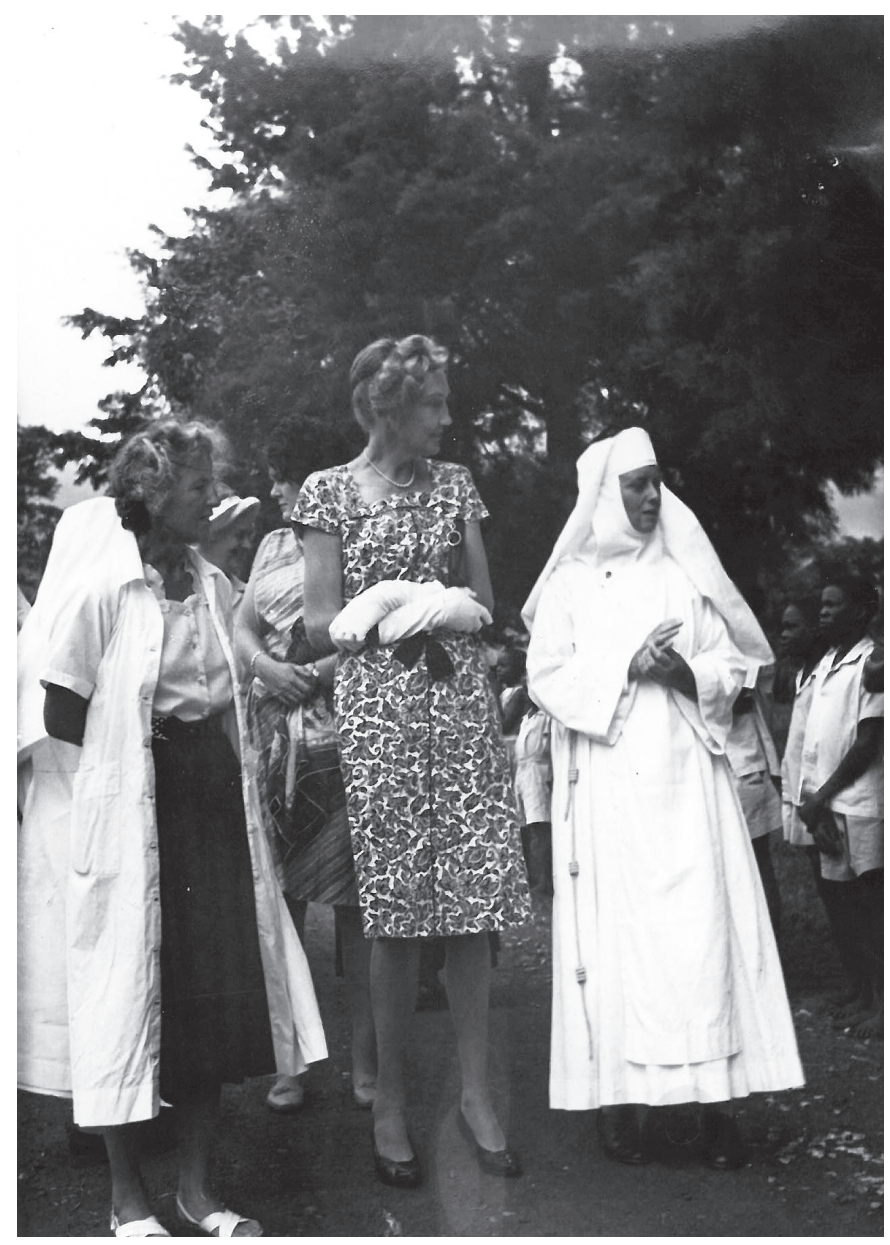




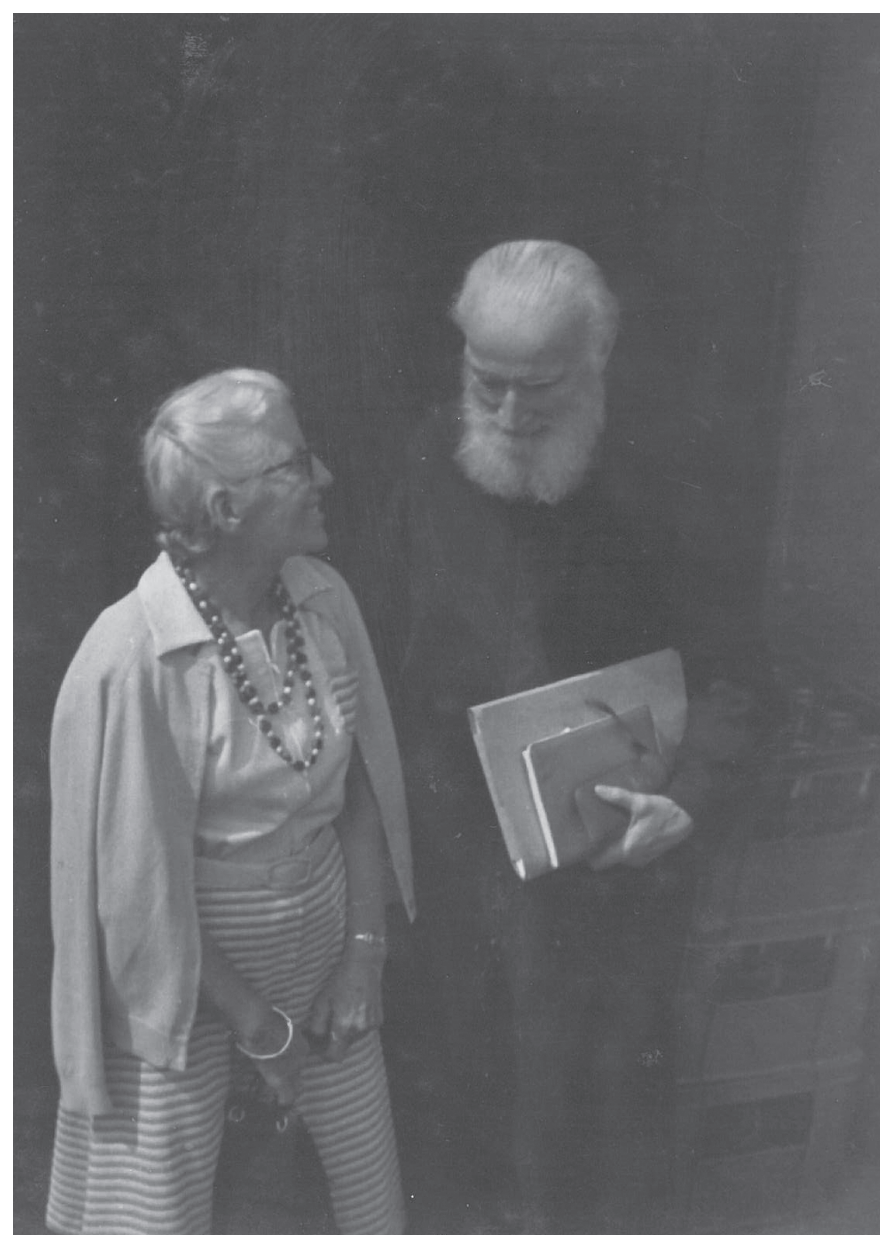

